Bojan Krstić ${ }^{1}$

University of Niš, Faculty of Economics

Ernad Kahrović ${ }^{2}$

State University of Novi Pazar,

Department of Economic Sciences

Tanja Stanišić3

University of Kragujevac, Faculty of Hotel Management

and Tourism in Vrnjačka Banja
ORIGINAL SCIENTIFIC ARTICLE doi:10.5937/ekonomika1504021K

Received: October 23, 2015

Accepted: November 16, 2015

\title{
BUSINESS PROCESS MANAGEMENT IN HOTEL INDUSTRY: A PROPOSED FRAMEWORK FOR OPERATING PROCESSES ${ }^{4}$
}

\begin{abstract}
The purpose of this paper is to develop a generic hotel enterprise framework for operating business processes. That framework will encourage hotel and lodging enterprises to see their activities from a cross-industry process viewpoint instead of a narrow functional viewpoint. The process oriented perspective of business and hotel enterprises may surmount many of the weaknesses of the classical functional organizational structure and vertical management. The transformation of a hotel organization towards a business process management system with horizontal or process management point out the need to leave functional organizational in a hotel, and directs attention of its managers to different types of business processes: operating processes, management processes and support processes. Operating processes are a complete, dinamically coordinated and measurable set of activities or logically related tasks that use one or more input and produce outputs, at the same time creating value for hotel guests. This paper develops classification of operating business process on: the process of hotel housekeeping, the process of supplying necessary inputs, the process of guests arrivals and departures and the process of producing and serving food and beverage. The proposed framework for operating processes are very useful for hotel managers in Serbia, since they point out the relevance of more consistent application of business process management system in dayto-day business activities with the aim of effective decision-making.
\end{abstract}

Key words: process management, operating process, hotel industry

JEL classification: M11, M21, O31, L83

\footnotetext{
${ }^{1}$ bojan.krstic@eknfak.ni.ac.rs

2 ekahrovic@np.ac.rs

3 tanja.stanisic@gmail.com

${ }^{4}$ Paper is a part of research within the project No. 179066 financed by the Ministry of Education, Science and Technological Development of the Republic of Serbia.
} 


\title{
УПРАВЉАЊЕ ПОСЛОВНИМ ПРОЦЕСИМА У ХОТЕЛСКОЈ ИНДУСТРИЈИ: ПРЕДЛОГ ОКВИРА ЗА ОПЕРАТИВНЕ ПРОЦЕСЕ
}

\begin{abstract}
Апстракт
Циљ овог рада јесте развијање оквира пословних процеса хотелских предузећа. Поменути оквир ће омогућити предузећима која се баве хотелским бизнисом и пружањем услуга смештаја да реализују своје активности из угла пословних процеса уместо угла пословних функиија. Имплементација процесне оријентације код хотелских предузећа може утииати на елиминисање недостатака функиионалног организовања. Трансформачија хотелских организација према систему управљања коришћењем пословних прочеса наглашава потребу да се напусти функционална организациона структура у хотелским предузећима, и усмери пажьа менацмента ка различитим врстама пословних прочеса: оперативним пословним процесима, управљачким пословним процесима и прочесима подршке. Оперативни процеси су потпуни, динамички координирани и мерлив скуп активности или логички повезаних задатака који користе један или више улаза и производе услуге, истовремено стварајући вредност за хотелске госте. Овај рад развија класификацију оперативних пословних прочеса на: прочес хотелског домаћинства, процес снабдевана неопходним инпутима, процес пријема и испраћаја гостију и прочес производње и сервисирањ а хране и пића. Предложене графичке интерпретације су веома корисне за хотелске менаиера у Србији, јер они наглашавају потребу за већом применом прочесног приступа у управљању у свакодневним пословним активностима и ефективном доношењу одлука.
\end{abstract}

Кључне речи: процесни менациент, оперативни процеси, хотелска индустрија

\section{Introduction}

The three biggest challenges for hotels' organizational structure are: globalized business environment, technology development and request of interested parties. The first challenge is the increasingly competitive environment of the hotel and lodging enterprises in all geographic regions. While some temporary aberration may result in less opposition, the forces that are shaping the hotel industry dictate that intense competition in all business sectors will be the rule and not the exception. The second challenge is the tremendous increase in the sophistication of information technology and social network of hotels. And third, always promising, challenge are requests of hotel guests. In response to the mentioned challenges, hotel enterprises are forced to innovate faster their business models and must focus on customers, competition and processes. These new business models have been described as "'business process management system" (BPMS). This system means that a focus is placed on the business process (Krstić, Jovanović, Kahrović, 2012).

The functional structure of hotel organization will not be sufficient for a longrun answer to aforementioned challenges. Classic structural model of hotel organisation must be upgraded through developed, documented and implemented business process. In order to run hotel successfully, numerous interrelated activities must be defined and 
managed. The implementation of business process management systems in the hotel enterprise, their definition and interaction, together with the management, can be defined as a business process approach of management. Business processes are one of the important elements of hotel management system. If they are not developed, documented and implemented, we can fairly ask whether the hotel management system is capable of meeting requests of interested parties, primarily hotel guests.

\section{Theoretical backgrounds and literature review}

Organizing, the process of structuring human and physical resources in order to accomplish organizational objectives, involves dividing tasks into jobs, specifying the appropriate department for each job, determining the optimum number of jobs in each department, and delegating authority within and among departments (Burton, Obel, DeSanctis, 2011). One of the most critical challenges facing hotel and lodging business is the development of a responsive organizational design that is committed to better hotel guests and employee satisfaction, financial performance and competitive advantage.

Most small and medium sized-enterprises, including hotels, have been organized in the same way for years. Hotel managers are faced with the need to group certain jobs in order to ensure efficient coordination and control of activities. These job groupings are usually called departments. This common method of organizing a hotel or a lodging business is the functional organization. In a very small lodging business, such as bed-andbreakfast, the owner can supervise each department. However, as the lodging business increases in size, it is effective to create a managerial position within departments (Stutts, Wortman, 2006). That means that workers who perform similar operations or have similar knowledge are grouped together into one department. This way of organizing is based on the notion that greater productivity can be achieved when workers specialize in just a few tasks or activities. The division of work, where employees are appointed only one or a few specialized operations and are provided with specialized machines to help them perform those operations, can result in greater output per worker than could be accomplished by the same number of specialists each working alone.

In a functional organizational designed enterprise, each hotel department is organized narrowly around the particular function it is intended to perform. A detailed analysis of the organization, duties, and requisite skills of the members of each department would demonstrate a high degree of consistency of purpose, a logical hierarchy of position, and a somewhat common body of skills. The narrow focus within each department fosters departmental efficiencies and clarity of departmental goals and career paths. However, owing to the narrow focus, many of the skills learned in one department are not easily transferable to other departments. Moreover, the narrow focus of the departments also makes it difficult for members of one department to fully understand or appreciate the contributions of other departments.

Functional hotel departments can be depicted as watertight cylinders. Each department is designed to perform certain functions and has become efficient in channeling information and work both upward and downward within its cylinder. The flow of information or the coordination of activities among cylinders tend to be difficult, however. Career paths are strictly within a single department and, as each becomes 
absorbed with its own activities, tasks, and goals, departmental viewpoints become more myopic and the opportunity for interdepartmental dispersion of ideas and cooperation becomes more difficult. In addition to these, there are also a few weaknesses of functional organizational design in hotel organisations (Nebel III, Rutherford, Schaffer, 1994): 1) Central decision making (authorization for purchases often must be signed by general managers); 2) Difficulty of cross-functional coordination (the coordination of activities requiring the cooperation of more than one department represent a major organizational challenge for hotels); 3) Stifled innovation (central decision-making and coordination often results in a bureaucracy that focuses power in hands of one or only a few people at the top of the organization); 4) Unclear responsibility for overall performance; 5) Limited opportunities for general management training.

Appropriate way to overcome these weaknesses of a functional organizational design in hotel organizations is to develop interdepartmental teams to help coordinate the activities of different departments that must work together. Properly designed interdepartmental teams improve communication among departments that serve each other's customers and provide a forum for averting problems. Teams foster direct communication among members of different departments, but they are also time-consuming and add an additional element of complexity to an already complex organization. In addition, while providing the opportunity for coordination and cooperation, they do not ensure it.

It is possible to introduce a new way of viewing hotel organizations that hold the promise of overcoming many of the inherent weaknesses of a functional organization and, at the same time, is more in tune with the operational imperatives of the hospitality business. This approach challenges the principle of division of labour. The fundamental premise of this management system is that hotels currently organized by departments around tasks should reunify those tasks into coherent business processes. Furthermore, arranging business activity into business processes will dictate what the organization will look like. Thus, to understand how the hotel of the future might be organized, it is necessary to approach the task indirectly by first understanding the concept of business processes and business process management system.

Developing a new management system of the hotel organization requires a new way of thinking, which will result in dramatic business performance improvements. This new way of viewing the organization has been typically described as a business process management system (BPMS). Business process management system or business process orientation (BPO) was actually introduced thirty years ago by Porter (1985). He introduced the concept of interoperability across the value chain and horizontal organization as a major issue within firms (Porter, 1985). Davenport and Short (1990) also depicted a process orientation within a company as a crucial component for success. They defined a process orientation as a horizontal view of business that cuts across the organization with product inputs at the beginning and outputs and customers at the end. They suggested that five major steps in process redesign are: developing the business vision and process objectives, identifying the processes to be redesigned, understanding and measuring the performance of existing processes, identifying IT levers, designing and prototype process (Davenport \& Short, 1990). 
Furthermore, Hammer and Champy (1993) presented the business process orientation concept as an fundamental element of an effective reengineering effort in the most influential business management book ' Reengineering the Corporation: A Manifesto for Business Revolution." They offered reengineering as a strategy to overcome the problematic cross-functional activities that present major performance issues to firms. The apparent conflict between a functional focus ("whom I report to") vs. a horizontal focus ("whom I provide value to") is offered by them (Hammer \& Champy, 1993). Along with them, Bryne (1993) among the first popularized the term "horizontal organization" and provided a prescriptive definition of a business process-oriented model. A process oriented organization is also often referred to as a "process centred organization" (Hammer, 1996), "'horizontal organization" (Ostroff, 1999), " "process enterprise" (Hammer \& Stanton, 1999), "'process focused organization" (Gardner, 2004), "process managed organization" (Rummler, Ramias $\&$ Rummler, 2006). Numerous authors have researched the idea of organizing around business processes in a certain manner (Stalk \& Black, 1994; Dutta \& Manzoni, 1999; Ostroff, 1999; Galbraith, 2002; Gardner, 2004; Crosetto \& Macazaga, 2005; Weske, 2012).

All of them considered that the scheme of the functional hierarchy could not provide a true picture about how an enterprise operates. Therefore, it is necessary to work on the identification of a business processes network, and by the implementation of the principles of BPMS to provide the managing of the enterprise. Besides, the processoriented enterprise is being created with the help of transformation of the functional structure into the process structure, and instead of functional departments, business process is used as a base for grouping the jobs. This means that jobs are not grouped according to similarities as is the case with the functional grouping, but according to their connectivity with a certain business process. Thus, instead of a traditional functional department, such as a personal, accounting, marketing, engineering, purchasing, rooms division and others, there are process teams which consist of all activities that are in function of the effective realization of some process.

The three fundamental principles of BPMS are (Ostroff, 1999, p. 10): 1) organize around cross-functional business processes, not functions; 2) install process owners or managers who will take responsibility for the certain process in its entirely; 3) make teams, not individuals, the cornerstone of organizational design and performance. According to Davenport and Short (1990), business process is "a structured, measurable set of activities designed to produce a specific output for a particular customer or market." Another comprehensive definition about cross-functional business processes are given by BPR experts Hammer and Champy (1993). They focused on the external dimension of a business process, pointing out that "it is a set of activities that use one or more input and produce outputs at the same time creating value for consumers." Rummler and Brache (1995) described the business process as a way of managing white space on the organizational chart. They wanted to emphasize the horizontal nature of business process, which covers the space between different functional departments in an organization, because numerous problems in everyday operation between functional departments may appear. McCormack and Johnson (2001) define a process as a specific group of activities and subordinate tasks which results in the performance of a service that is of value. Business process design involves the identification and sequencing of 
work activities, tasks, resources, decisions, and responsibilities across time and place, with a beginning and an end, along with clearly identified inputs and outputs (Krstić, Kahrović, 2015).

The existence of process owners, i.e. persons responsible for the realization of a business process is the most obvious difference between process oriented and traditional functional enterprises (Kohlbacher, Gruenwald, 2011). The term "'owner of the process" is taken from the practice of TQM which can lead to some terminology problems. Process owner is not project manager, but it is a permanent role of one person responsible for realizing a business process. Owner of a process is responsible for the business process effectiveness and business process efficiency (Harrington, 2006, p. 47).

Process ownership is a very important element of the BPMS. The mission of the process owner is defined as: ensure efficient and effective business processes across organizational structures linking the value expectation and operational performance, manage and develop own processes and responsible for and mandate to define, implement, as well as measure and improve the owned processes as needed.

After choosing the person responsible for process realization, election of process team members is next. The owners of a process are forming process teams by selecting employees, which provide a contribution to achieving team goals and organizational objectives. A team is possible to define as a group whose members have corresponding skills and are grouped around a common purpose or set of tasks, for the realization of which they have certain responsibilities (Mohrman et al., 1995, p. 148). Process team means a group that focuses on a single business process to achieve continuous integration of its activities and ensure its realization in the desired way. Process teams are formed as permanent or temporary. Permanent process teams continually participate in the realization of repetitive business processes, and are therefore largely formalized. They mainly focus on the processes of the usage of various material and intellectual resources in the enterprise owing to be efficient. For example, process teams involved in providing services to consumers are permanent. Besides them, other process teams are only temporary and are established for special projects within a limited period of realization. For example, the process team which is formed to develop a new product can be treated as temporary.

\section{Process classification framework in hotel industry}

Business processes can be classified in several ways. Keen (1997) suggests that relevant processes are those that create value, processes that provide options and processes that sustain the value. According to Harrington (1997) the following activities within a business process are considered important: a) high-value adding activities, b) value adding activities and c) low-value adding activities. Following Harmon (2005), the crucial business processes are the following: core processes, enabling processes, and managerial processes.

Despite numerous possible types of business processes, and numerous diversities of process structures, all business processes in a hotel can be divided into three types (Figure 1): operating processes (processes that create, produce and deliver products and services that hotel guests want), supporting processes (processes that do not produce 
output for hotel guests, but which are necessary to start up a business) and managerial processes (Cerović, 2010, pp. 415-416).

Four key operating processes in the hotel are: 1) the process of hotel housekeeping, 2) the process of supplying necessary inputs, 3) the process of guests arrivals and departures and 4) the process of producing and serving food and beverage.

Supporting processes are: understand markets and services, develop vision and strategy, design hotel products and services and market and sell. Understand markets and services comprised of three activities: determine customer needs and wants, measure customer satisfaction and monitor changes in market or customer expectations. Main activities within a process of develop vision and strategy are: monitor the external environment, define business concept and organizational strategy, design the organizational structure and relationships between organizational units and develop and set organizational goals. Design products and services activities are: develop new product/service concept and plans, design, build and evaluate prototype products and services, refine existing products/services, test effectiveness of new or revised products or services, prepare for production and manage the product/ service development process. And, the last support process is market and sell, which comprised of next activities: market product or services to relevant customer segments and process customer orders.

Operating and supporting business processes have several important characteristics. Both types of processes have a set of related and interdependent activities which transform inputs into outputs. Operating and supporting processes have the beginning and the end, with boundaries which can be defined with reasonable precision and minimal overlap. These processes have users or customers that can be internal or external for an organization.

Besides these two species, the group of business processes includes managerial processes. These processes are a set of activities to direct, coordinate, integrate and control operating and supporting business processes that create value for enterprise consumers and shareholders. Management processes or managerial processes include mainly decision making activities. They are not tied to just one segment of an organization, but permeate the entire enterprise. Management processes include: develop and manage human resources, manage IT, manage financial and physical resources and manage reputation, quality and change. For managerial processes it can be said that they constitute a separate and essential subset of the supporting processes. They are not essential to consumers, but they are essential for management of an enterprise to provide survival, competitiveness and development of an enterprise. The difference between managerial processes is determined by the specificity of management objects. 
Figure 1. Process classification in hospitality

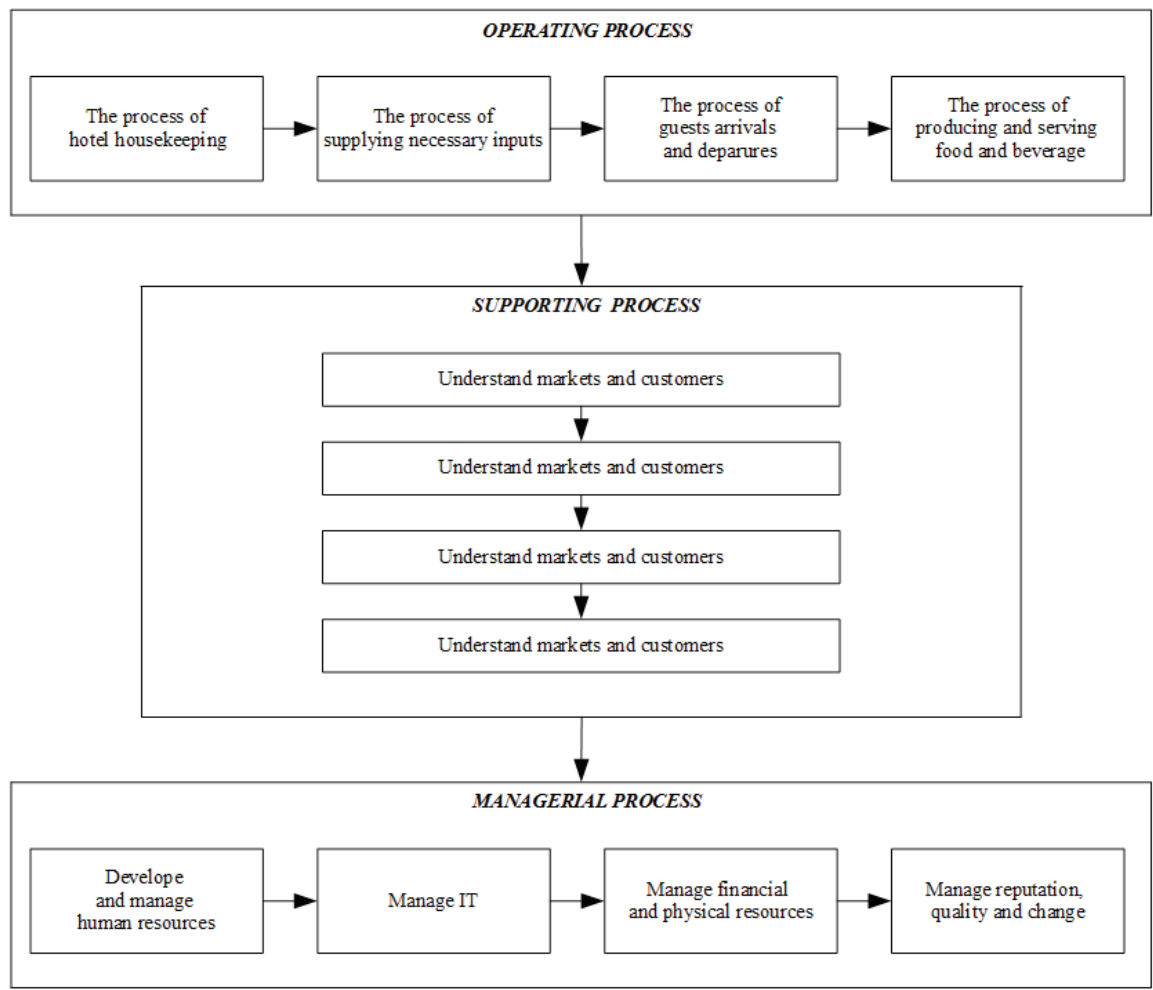

Source: Prepared by the authors

\section{Developing a framework of operating processes}

Complete operating processes of a hotel comprise of processes of production activities and service activities. The purpose of production activities is rendering of services which have product characteristics, like: various food, drinks that are specifically prepared, bread, desserts, and similar. Purpose of service activities is providing hotel guests with: accomodation, serving of meals and beverages, entertainment, sale of goods, various handicraft-and-services, laundry washing, ironing and similar. The most important operating processes break into its various activities. The description of each operating process is accompanied by a graphic interpretation that illustrates the interrelated activities.

The process of hotel housekeeping is an essential and basic part of the hotel guests experience and satisfaction. Reservation and producing food are also important, but what guests really want is to feel at home, to feel comfortable. Altough the staff giving this service do not necessarily interact with the public, the quality of their work is basic in molding hotel guests' pleasant memories of their stay. Satisfactory realization of this 
process is the foundation of good infection prevention. The general cleanliness, hygiene and technical maintenance are vital to the health and safety of guests, staff, and visitors. Pleasant work environment contributes to staff members' satisfaction, making them to be more productive. A more wonderful environment enhances hotel guest satisfaction and can increase guest's use of service and frequent visits.

Within the process of hotel housekeeping is possible to identify the following activities with employed persons (Figure 2): the activity of hygiene and equipment supplies accommodation units, bad making (supervisor room, maids), the activity of laundry and dry cleaning: washing, ironing, drying (head wash, the controller receiving and issuing machine, chemical cleaners, tailor, washer, presser), activity hygiene hotel public space (hygienist, washer floors, washer glass surfaces), safety and security, activity decorating the interior of the hotel and the maintenance of horticultural seedlings (decorator, florist, gardener), as well as technical maintenance activity.

Activity of hygiene hotel rooms mean cleans the rooms and wash basins in the room. Bed making is the dexterity that desire to be developed by the housekeeping staff, as it not only provides relaxation to the hotel guests, as well as adds to the wonderful feeling of a visitor's room. Laundry and dry cleaning have to ensure clean and hygienic washing of all the linen items, and then distributing them to different areas of the hotel.

Figure 2. The process of hotel housekeeping with accompanying activities

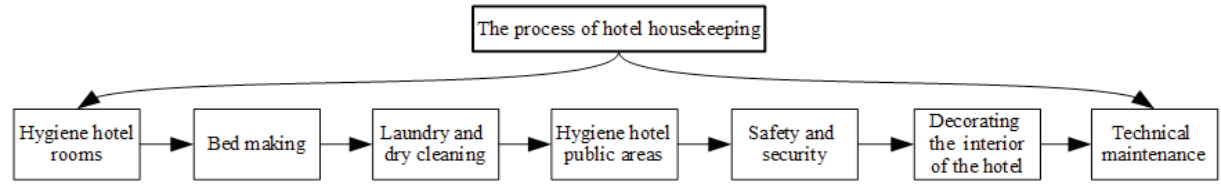

Source: Prepared by the authors

Aside from cleaning the guest rooms, housekeeping process is also obligated for cleaning floor, elevators, terraces, service lobbies and service stairways, function rooms, shopping arcade, cabanas, bars, dinning rooms, offices, uniform rooms, tailor rooms, upholstery, shops, strore rooms and swimming pools. To be concise, hygiene hotel public areas is responsible for the total cleanliness of a hotel (O'Fallon, Rutherford, 2010, p. 152).

Safety and security is responsible for maintaining a peaceable atmosphere in the hotel. If the guests always panic for their safety and the safety of their personal property, the climate will be exceptionally strained. Hence the housekeeping process staff should be aware of ways to protect himself and others, especially the guests around him and the property of the hotel from accidents. Several accidents could occur at the place of work. These include fire accidents, falls, wounds, injuries etc. It is imperative for all housekeeping staff to know about first aid as they could be the first ones on the spot to give quick regard to a hotel guests and also an employee in trouble.

Interior decoration is the craft of of making a pleasant atmosphere in the living room with the addition of a complex of furnishings, art, and crafts, appropriately combined to achieve a planned result or design. These expressions and specialties have to be well maintained by the process of hotel housekeeping. Decorating flowers is an 
ingenious and stimulating art which often carries a message or theme. Flowers and indoor plants add colour and beauty to a room.

As regards the activities of technical maintenance, it is necessary to point out that they ensure the functioning of the equipment and facilities in the hotel building. Maintenance hotel characterized by numerous distinctions, in relation to the facilities in which provide only food and beverage services. For staying in a hotel, in addition to board and lodging, requires the existence of a number of devices and equipment that are not required for restaurants. Rooms should have sanitary facilities, hot water, heating, TV, air conditioning, wi-fi internet, telephone and other elements necessary to stay in it. Longer stay guests at the hotel presupposes the existence of numerous hotels outside activities (sports and recreation, congress and business, spa-rehabilitation, etc.) which requires the existence of adequate equipment and devices. The objective of this task is to perform regular check of the equipment and devices, occasionally activated, a security officer of spare parts and, if necessary, in repairs or replaces the elements that are not in use (Stutts, Wortman, 2006).

At the head of the household is the owner of the hotel housekeeping process that includes the following activities: planning staff, schedule saving and sorting rooms and public spaces and the overall aesthetic appearance of the hotel. Just such an organization hotel housekeeping, of course, rarely encountered in practice and is subject to change depending on the type, size, location and method of doing business hotel. For example, some city hotels do not have a yard, or the surrounding area, and in these hotels, there is no need for external horticultural maintenance. In smaller hotels is definitely smaller and the number of employees, so the hotel can be hired farm just a few workers.

The process of supplying necessary inputs includes providing various kinds of goods and materials for the hotel business as a whole. Operation activities within this business process depends on the kind, type, size and category of hotel, as well as the time of its operations. These elements preferably influence the range and quantity of necessary goods and materials. Consumables character of the material, or the need for its continuous renewal, conditioned by the continuity of the business process. Given that certain types of goods and perishable foods subject, there is no possibility of forming a stock of goods of that kind, or the process requires special conditions for its storage.

The activities of this business process related to (Figure 3): selection of the best suppliers, ordering food and drinks, quantitative and qualitative reception of food and beverage, warehousing and goods issue. The owner of this business process evaluates and selects suppliers based on their ability to supply product in accordance with the requirements of the hotel. Owner process can by the contracting authority, inter alia, to set requirements that relate to the possession of precisely defined quality standards (ISO 9001.2008, HACCP, etc.). After the ordered food and drinks, the owner of the process with his team performs a set of operations that are related to the acquisition of foods and drinks, such as delivery of merchandise, unloading, the release of the packaging, weighing and storage. Foodstuffs are shipped in appropriate packaging which is an important condition for hygienic and health safety. Receipt of goods from suppliers accompanied by appropriate documentation, conducted by the owner of the process. The acknowledgment of receipt of the goods is evidence that the goods received are reviewed, tested, compared with an order form, and matches all elements in terms of quantity, quality and price.

After that is done warehousing and food in warehouses. There are the following types of warehouses: warehouses of food (dry food storage, storage of perishable food, a 
warehouse for fruits and vegetables, refrigerators and other cooling devices), warehouse chemistry and pair confection, warehouse for drinks, juices and mineral water, warehouse for linens (tablecloths, tablecloth and napkins), warehouse for porcelain, glass and silver cutlery. This process ends with the release of the goods production process and serving of food or housekeeping process, depending on their needs (Barjaktarović, 2013).

Figure 3. The process of supplying necessary inputs with accompanying activities

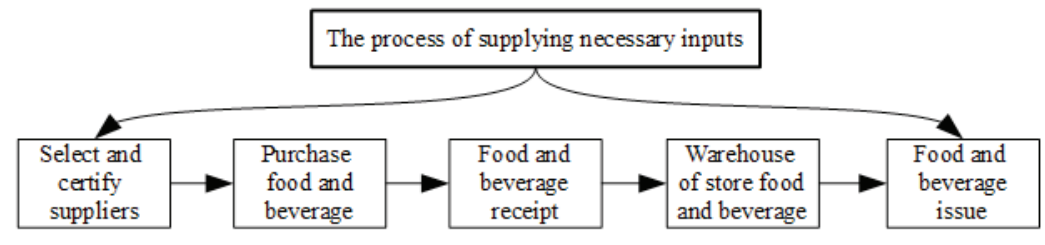

Source: Prepared by the authors

The process of guest arrivals and departures is a central spot of communication with guests at all stages of their stay in the hotel (from booking to payment of hotel bills). The process of guests arrivals and departures can be divided into five main activities. Within these five activities there are important tasks and operation related to guest services and guest accounting. Front office employees must be aware of guest services and guest accounting activities at all stages of the guest stay. Front office staff can viably serve the hotel visitors if they have a reasonable understanding of the flow of this process in hotel. The process of guests arrivals and departures represents a systematic approach to front office operations.

The guest chooses a hotel during the pre-arrival activity of this process. Choice of the guest can be affected by many factors, including previous experiences with the hotel, advertisement, word of mouth referral by friends and colleagues, location, corporate, travel agent booking, hotel name, hotel loyalty program member etc. The guest's decision of making the reservation can also be effected by the ease of making the reservation and the way reservation agent interacted and described the facility of the hotel like room type, room rate, recreational facilities and other attractions near the hotels etc (Barjaktarović, 2013, p. 137). If a reservation can be accepted, the reservation agent create a reservation on the hotel management software. The creation of this reservation record starts the hotel process of guest arrivals and departures. This reservation contains details of guest specific request which will help the hotel to provide the guest with personalized service during his stay.

Figure 4. The process of guests arrivals and departures with accompanying activities

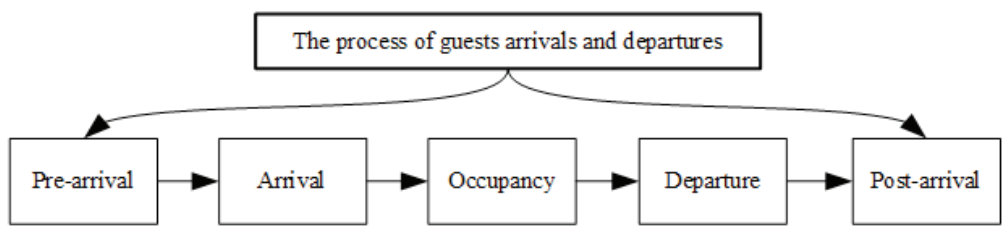

Source: Prepared by the authors 
Reservations can be divided in different ways. With regard to the temporal aspect, reservations can be short and long term, while in terms of security of payment bookings can be guaranteed and unguaranteed. Short-term reservations related to the situation when the reservation request submitted several days before the beginning of the service, and relate mainly to individual customers. On the other hand, when the request is submitted several months earlier and refers to a longer period of use of hotel services, such form is called long-term reservations. Guaranteed reservations imply a specific form of guarantee hotel by a client that contracted services are implemented within the stipulated period. These reservations are favorable variant for the hotel. Unguaranteed are mainly occurring in transient objects a high level of occupancy. In the case of a guest who has reserved service does not appear until a certain time reserved a hotel room may issue another client.

The arrival activity of this process includes registration and room assignment process. After the guest arrives, he or she establishes a business relationship with the hotel through front office. It is the front office staff responsibility to clarify any query of the guest especially the details of room rate of packages he /she is booked on. When the guest checks-in to the room the occupancy stage of the guest cycle begins. The manner in which the front office staff represents the hotel is important amid the occupancy stage. As the main contact centre for hotel activity, the front office is responsible for coordinating guest requests. Among those providing information and supplies to the guests. Front desk should take extra care to respond to the guest on a timely and accurate manner. The main focus of the front desk staff is to provide anticipatory service and to meet or exceed the guests expectations. This will encourage the guest to repeat to the hotel.

A variety of charges restaurant charges, telephone, internet, travel desk etc. during the occupancy stage affect guest and hotel account. Most of these charges will be posted to the guest account according to front office posting procedures. Other front office financial tasks during the occupancy stage is to verify the charges posted to the guest account and checking guest accounts against the credit limit. Guest services and guest accounting aspects of the process arivalls and departures are completed during the cycle's fourth phase i.e. departure. At departure the guest vacates the room, receives the accurate statement of the settled accounts, returns the room keys and leaves the hotel. Once the guest has checked out, front office updates the rooms availability status and notifies the housekeeping department. For hotels using property management software the status of the room is updated automatically. At this stage front office also collect the feedback of the guest experience in the hotels by handing over the guest feedback form.

The primary function of the process of producing and serving food and beverage is to provide food and drink to a hotel's guests. There is great diversity in the activities performed by this process, requiring a significant variety of skills on the part of its workers (Stutts, Wortman, 2006). This process have duties in producing, serving and selling food and beverages in hotel. Also, the process is divided into two sub-processes those are food and beverages product and food and beverages service.

The process of producing and serving food and beverage comprises a number of activities that may be performed in one or more types of kitchens. The number of activities and the type of kitchen or kitchens depend on the characteristics of the specific operation-large or small, cafeteria or table service, limited menu or extensive menu, and so forth. Typical most important activities within this process include: preparation and 
pre-treatment of food, finishing, thermal and finishing food stuffs, preparation of cold appetizers, cold dishes and salads, preparation of sweet dishes and desserts, and serving food and beverage (Figure 5).

Figure 5. The process of guests arrivals and departures with accompanying activites

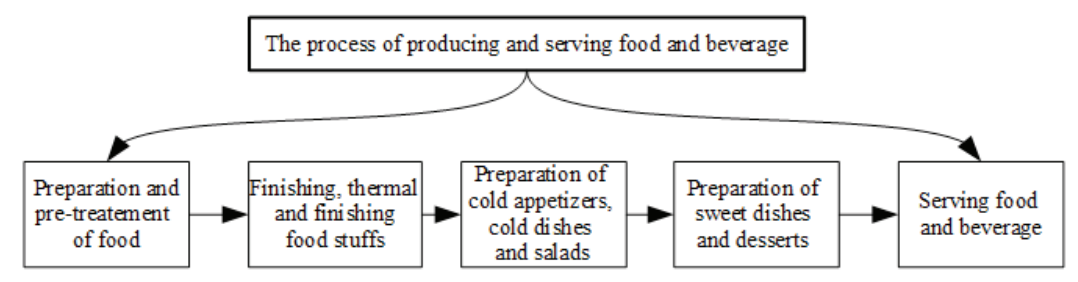

Source: Prepared by the authors

These activities of the process of producing and serving food and beverage are usually worked in kitchen, banquet, bar or lounge, room service and pastry shop. All of these activities is possible to divide in a lot of tasks and operations depending on the type, size or location of hotel enterprise.

\section{Conclusion}

Advantages of the business process management system of hotel enterprises compared to the functional model of organizational structure are reflected in performing operating business processes and activities with higher level of efficiency. It dramatically increases the flexibility of a hotel enterprise, capacity for innovation and speed of innovation process according to hotel guests demands. Because there are no boundaries between functional departments, employees increasingly recognize organizational objectives as their personal objectives, which ultimately results in their larger contribution to competitive strategy and its faster realization. The proposed framework for operating processes promotes and emphasizes teamwork and cooperation. Business process management system focuses all its attention on hotel guests, which leads to their greater satisfaction, improved work productivity and profitability.

\section{References}

Barjaktarović, D. (2013) Upravljanje kvalitetom u hotelijerstvu, Univerzitet Singidunum, Beograd

Burton, M.R., Obel, B., DeSanctis, G. (2011) Organizational Design - a step by step approach, Cambridge University Press

Byrne, J.A. (1993) The Horizontal Corporation, Business Week

Cerović, Z. (2010) Hotelski menadžment, Sveučilište u Rijeci

Davenport, T.H., Short, J. (1990) The New Industrial Engineering: Information Technology and Business Process Redesign, Sloan Management Review, Fall, 11-27. 
Galbraith, J.R. (2002) Designing Organizations: An Executive Guide to Strategy, Structure, and Process, Jossey-Bass, San Francisco, CA.

Gardner, R (2004) The Process-Focused Organization, Quality Press, Milwaukee, WI.

Hammer, M., (1996) Beyond Reengineering: How the Process-Centred Organization Is Changing Our Work and Our Lives, Harper Collins Publishers, New York

Hammer, M., Stanton, S. (1999). How Process Enterprises Really Work, Harvard Business Review, 77 (6), 108-118.

Hammer, M.H., Champy, J. (1993) Reenginnering the Corporation: A Manifesto for Business Revolution, Harper Business, New York, NY.

Harmon, P. (2005) Business Process Change: A Manager's Guide to Improving, Redesigning, and Automatic Processes, Morgan Kaufmann Publishers, San Francisco, CA.

Harrington, J. (2006) Process Management Excellence - The Art of Excelling in Process Management, Paton Press LLC, California

Krstić, B., Jovanović, S., Kahrović, E. (2012) Process-oriented enterprise as a determinant of organization behavior in contemporary business term, Actual Problems of Economics, 11 (137), 369-379.

Krstić, B., Kahrović, E. (2015) Business process outsourcing as a tool for improving enterprise efficiency, Ekonomika, 61(3), 31-41.

Keen, P.G.W. (1997) The Process Edge-Creating Value Where It Counts, Harvard Business School Press, Boston, MA.

McCormack, K.P., Johnson, W.C. (2001) Business Process Orientation: Gaining the E-business Competitive Advantage, St Lucie Press, Boca Raton, FL.

Mohrman S. A., Cohen S. G., Mohrman A. M. (1995), Designing Team-Based Organizations - New Forms for Knowledge Work, Jossey-Bass, San Francisco

Nebel III, E.C., Rutherford, D., Schaffer J.D (1994) Reengineering the Hotel Organization, Cornell Hospitality Quarterly, 35 (5), 88-95.

Ostroff, F. (1999), The Horizontal Organization, Oxford University Press, Oxford

Porter, M.E. (1985). Competitive Advantage: Creating \& Sustaining Superior Performance. New York, NY: The Free Press.

Rummler, G. A., Ramias, A., \& Rummler, R. A. (2009). White Space Revisited: Creating Value Through Process, San Francisco, CA: Pfeiffer.

Rutherford, D., O'Fallon, M. (2010) Hotel Management and Operation, John Wiley \& Sons, Inc

Stalk, G., \& Black, E. (1994). The Myth of the Horizontal Organization. Canadian Business Review, 21(4), 26-29.

Stutts, A.T., Worton, J.F. (2006) Hotel and Lodging Management: An Introduction, John Wiley \& Sons, Inc

Weske, M. (2012) Business process management - concepts, languages, architectures, Second edition, Springer 